\title{
Equine Theileriosis: Review
}

\author{
Ana Muñoz Vianna ${ }^{1,2}$, Ana Paula de Souza Stori de Lara ${ }^{3}$, Guilherme Borges Weege ${ }^{3}$, Rodrigo Casquero Cunha ${ }^{2}$ \\ and Fábio Pereira Leivas Leite ${ }^{1,2 *}$
}

${ }^{1}$ Department of Microbiology and Parasitology, Federal University of Pelotas (UFPel), Brazil

${ }^{2}$ Postgraduate Program in Veterinary Medicine, Federal University of Pelotas (UFPel), Brazil

${ }^{3}$ Department of Microbiology and Parasitology, Federal University of Pelotas (UFPel), Brazil

Submission: June 06, 2018; Published: September 28, 2018

"Corresponding author: Fábio Pereira Leivas Leite, Veterinary Graduate Program Federal University of Pelotas - UFPel, Capão do Leão Campus, Pelotas, RS, Brazil, Tel: 55 (53) 32757350; Email: fabio@leivasleite.com.br

\begin{abstract}
Equine theileriosis, caused by the Apicomplexa protozoan Theileria equi, is an intra-erythrocytic parasite disease found in horses, and it is widely distributed throughout the world. Its prevalence and endemicity are linked to the presence of tick vectors and chronic equine carriers. Diagnosis of theileriosis is based on serological methods, including ELISA (Enzyme-Linked Immunosorbent Assay), IFAT (indirect fluorescent antibody), and molecular methods such as PCR (Polymerase Chain Reaction). Theileria equi has merozoite surface proteins, equi merozoite antigens (EMA-1, EMA-2, EMA-3 and EMA-6). These antigens play an important role in pathogenesis and provide as host immune response targets against the parasite. EMA-1 and EMA-2 have been identified as immunodominant antigens and they are expressed on the surface of extra-erythrocyte merozoites. EMA-1 protein has been used in commercial testing of immunodiagnostic; however, EMA-2 is a highly conserved immunogenic protein and a promising target. The aim of this study is to contribute to improving the diagnosis and prevention of equine theileriosis.
\end{abstract}

Keywords: ELISA; Immunodiagnostics; Surface protein and Theileria equi

\section{Introduction}

Equine piroplasmosis, caused by the intracellular protozoa Theileria equi and Babesia caballi, belonging to the phylum Apicomplexa, is considered the most important horse disease transmitted by ticks [1]. The disease is caused by infection with Theileria equi, formerly Babesia equi [2] and is called equine theileriosis $[3,4]$. The phylum Apicomplexa includes a large group of organisms, including the order Piroplasmida, comprised of compulsory vertebrate and invertebrate parasites [5]. The organisms have an apical complex containing secretory organelles involved in invasion and the parasite remains within the host [5]. Theileria equi has a wide geographic distribution and infects horses in Europe, Asia, Africa and South and Central America, but is considered endemic in tropical and subtropical [6]. Equine theileriosis stands out as a major cause of both horse illness and of losses to the horse raising industry. Even with improvements in health, piroplasmosis causes losses associated with clinical factors and through international restrictions on the transit of seropositive animals $[7,8]$. Theileria equi is small, $2-3 \mathrm{~mm}$ in length [9], pleomorphic within erythrocytes, and is isolated in pairs or when forming tetrads (Maltese cross). When parasitemia is low, they are barely visible under the microscope and can be easily confused with technical artifacts due to their small size [7]. The parasite is carried by ticks, especially the genera Anocentor, Amblyomma, Rhipicephalus and Haemaphysalis [10]. Rhipicephalus microplus is considered the responsible for infestations in horses when sharing pastures with bovine [11,12].
When taking a blood meal on a host, (an infected equine), the tick vector ingests erythrocytes containing the gametocytes that in its intestines will give rise to the gametes that will fuse to form the zygote. The zygote differentiates to the mobile form ookinete which is transported through the hemolymph to the salivary glands of the tick. Within the salivary glands, sporoblasts, and finally, sporozoites will give rise (MEHLHORN \& SCHEIN, 1998.Theileria equi transmission occurs through tick blood meals which contain infective (sporozoite) forms (UILENBERG, 2006). Theileria equi exhibits a biphasic cycle in the mammalian host with an intra-leucocyte development phase followed by an intraerythrocytes phase (RAMSAY et al., 2013). The intra-leucocyte phase includes infection of $\mathrm{B}$ and $\mathrm{T}$ lymphocytes, monocytes, and macrophages. However, unlike others theilerias, the preerythrocytic stage of $T$. equi has not been clinically associated with disease, since it is not necessary to complete the lifecycle Ramsay et al. 2013. Approximately 2 days after infection T. equi schizonts begin to infect lymphocytes, and by 15 days merozoites can be viewed through blood smears in erythrocytes. The parasitemia reaches approximately $7 \%$ of the erythrocytes, but in immunocompromised animals it can reach $80 \%$ [14]. In nature, horses are T. equi reservoirs where transstadial transmission can occur [15]. In transstadial transmission, larvae that feed on infected horses are infected yet maintain sporozoites in their salivary glands. When changing into nymphs, these will then 
become infected, spreading the parasite. The nymph will give rise to an infected adult as well [16]. The adult $R$. microplus male realizes intrastadial transmission, or rather, acquires the parasite during its feeding on infected animals, both in the acute phase and in the chronic phase of the disease, and transmits the infection to other healthy animals [17].

Transplacental transmission of T. equi in horses has been reported in the United Kingdom, Trinidad, and India [18-21] and can result in miscarriages, stillbirths, or foals birthed with neonatal theileriosis [22]. In neonatal theileriosis foals are born looking healthy, but from 24-48 hours after birth begin to show the first clinical signs, such as severe weakness, severe jaundice, elevated temperature and high parasitemia [20]. Reproductive failure of mares, as a result of intrauterine fetus infection, particularly with T. equi, is quite common in some countries DE WAAL, 1992. Equine piroplasmosis can still be transmitted iatrogenically by common use of contaminated syringes and needles [23]. Equine theileriosis is a condition that may occur in acute, sub-acute or chronic forms. Acute cases are characterized by fever, anorexia, anemia, jaundice, hepatosplenomegaly, intravascular hemolysis, mucosal surface petechiae, hemoglobinuria, abortion and even death $[24,25]$. Abortion can occur between the second and eleventh month of gestation [21]. The symptoms are barely observed in animals from endemic areas, since foals receive passive immunity from the mothers. Foals produce their own antibodies gradually as they come into contact with the parasite [25]. In sub-acute cases the symptoms are the same, though milder and accompanied by weight loss and intermittent fever [26]. Chronic cases are the most common with nonspecific signs and in most cases the animals are asymptomatic [15]. However, they may have poor appetite, low physical performance and a decrease in body mass [26].

Parasitemia is often absent but may reappear with immunosuppression [27]. Immunocompetent animals recovering from acute infections become asymptomatic carriers and continue as T. equi reservoirs, maintaining (in the presence of the vector) disease endemicity $[22,15]$. These animals develop a protective immunity against clinical disease when re-exposed to the parasite. This protection has been attributed to continuous stimulation of the immune system by remaining parasites $[24,28]$. Animals infected with $T$. equi have responded with high antibody titers against merozoite surface protein [29]. Merozoite surface antigens play important roles in the pathogenesis of the disease through recognition, binding, and penetration into host erythrocytes. These proteins are expressed on the surface of red blood cells and are recognized by the equine immune system [29-31].

\section{Surface Antigens - Equi Merozoite Antigens (Emas)}

In T. equi, two merozoite surface proteins equi merozoite antigens (EMAs: EMA-1, $34 \mathrm{kDa}$, and EMA-2, $30 \mathrm{kDa}$ ), were shown to interact with erythrocyte cytoskeletons and identified as immunodominant antigens [32-34]. In addition, other surface antigens were identified previously (EMA-3, $25 \mathrm{kDa}$ and EMA-6, $34 \mathrm{kDa}$ ), but their exact identity is unknown [35] IKADAI et al. [36] described EMA-3 as a T. equi protein that adheres to the inside of the erythrocytic membrane and it may have important role in the replication of parasite after erythrocytic invasion [35]. These glycoproteins belong to the main family of piroplasmic surface proteins (MPSP) and are conserved within the Theileria genus [37-39]. The molecular mechanisms involved in these cellular interactions between the protozoa and the host cells are not fully known [40]. Apicomplexa parasites, including Plasmodium spp. and Toxoplasma spp. [41] use surface proteins for binding to the surface of erythrocytes, in horses however, the receptors involved in this process are unknown [42] [40]. Co-expression of EMA-1 and EMA-2 on the surface of free merozoites (extra-erythrocytic) has been demonstrated, however, they are not expressed in the asexual stage of merozoites in erythrocytes [30]. EMA-1 and EMA2 have $52 \%$ identity between their amino acid. In addition, they possess in their sequences a glycosyl phosphatidylinositol anchor (GPI), suggesting that the proteins are expressed on the surface of the merozoites, similar to other merozoite surface antigens from Babesia bovis, B. bigemina, Theileria annulata and T. sergenti [30]. The merozoites secrete EMA-2 and not EMA- 1 into the erythrocyte cytoplasm, and/or insert them on the membrane surface [30] [40]. Gene nucleotide sequences for the EMA-1 glycoprotein, which is used in official tests for theileriosis diagnosis [43], have shown differences from those already deposited in GenBank, even in Brazilian strains [7]. These differences may alter the specificity and sensitivity of diagnostic tests. Since they are highly conserved, the nucleotide gene sequences for the T. equi EMA-2 glycoprotein, did not show, until now, diversity in comparison with those already deposited in GenBank [44].

\section{Immune Response}

The responses correlate with control of parasitemia T. equiinfected horses produce antibodies against immunodominant merozoite proteins (EMAs). The exact role of this antibody response in immunity and persistence of disease remains unclear [45]. Persistent infection is characterized by variation in the levels of parasitized erythrocytes approximately between $10^{3.0}$ to $10^{6.0}$ parasites per $\mathrm{ml}$ of blood. The precise mechanisms of adaptive immunity to control equine theileriosis are not fully understood, yet they are undoubtedly complex, multifaceted, and necessary to control $[45,46]$. There is evidence that both humoral and cellular responses are involved. Although essential in other hemoprotozoan infections, such as, the immunity-mediated function in piroplasmotic cells has yet to be fully determined [45,46]. At erythrocyte lysis, the parasites become accessible to antibodies and their immune-mediated mechanisms [47]. Antibodies neutralize parasites, blocking their entry into cells, causing opsonization of infected erythrocytes, and eventually cell lysis [47]. However, high antibody titers alone are not able to protect against theileria infection [28].

Immunocompetent animals produce IgGa antibodies (IgG1) and IgGb $(\operatorname{IgG} 4,7)$ specific against merozoites during the acute phase of equine theileriosis, while IgG (T) (predominantly IgG5 and to a lesser extent IgG3) appears only after resolution of parasitemia (chronic phase) [28]. IgG1 immunoglobulins, IgG3, IgG4 and IgG7 activate the complement, interact with Fc receptors, 
and play an important role in resolving acute parasitemia [28]. In most endemic areas, colts that ingest colostrum from a theileriosis carrier mare are protected against infection and clinical disease during the first 1-5 months. When maternal antibodies decrease, the foals become susceptible to infection [45].

\section{Diagnosis}

Though differentiation between $T$. equi and $B$. caballi infections is important for success in the treatment and control of the diseases, they cannot be diagnosed based on clinical signs alone, they are not clinically distinguishable [48]. Theileriosis can be diagnosed by clinical signs associated with blood smears stained with Giemsa for parasite visualization in red blood cells. However, this method is flawed because of non-detection of the parasite in the blood of clinically normal and negligibly parasitized animals [49], it does not differentiate between the causative agents of piroplasmosis, T. equi and B. caballi, which can cause false-positive results [50], and due to its small size, $T$. equi can be confused with technical artifacts (KERBER, 2009). Theileria equi infections have been detected in both serologic and molecular assays [51]. Molecular and serologic tests are objective and accurate [50]. Conventional PCR has been performed using the 18S rRNA sequence from Piroplasma spp. [50,51] however, this molecular method, can fail in low parasitemia in animals in the chronic phase [50]. Usually, molecular assays are done in conjunction with serological tests such as IFAT and ELISA [50,51] or with parasitological tests and blood smears.

[1] used quantitative PCR (qPCR) for T. equi DNA detection in clinically healthy animals in an endemic area (Saudi Arabia). The complement fixation test (CFT) was widely used in the past in some countries and in certain regions continues to qualify horses for importation. It is an accurate method for detecting acute infections but does not identify animals that have been treated with drugs, moreover, IgG (T) the main immunoglobulin isotype of the chronic stage is unable to fix guinea pig complement [26]. Antibodies directed against merozoite surface proteins are important for immunity to infection by T. equi and therefore studies of immunological diagnosis of theileriosis focus on obtaining antigenic fractions of these proteins [33]. The sensitivity and specificity of immunological diagnostic tests depend on the antigen used. The use of recombinant antigens as specific and immunodominant epitopes reduces the generally observed cross reactions and unspecific reactions when total antigens are used. Therefore, it is plausible to use such recombinant antigens for $T$. equi detection $[31,44,52,53]$.

cELISA is based on the EMA-1 protein and a monoclonal antibody (MAb) specific to a protein epitope on the merozoite surface [43]. cELISA is superior, sensibility and specificity, in relation to IFAT and CFT [1] However, differences in cELISA and qPCR results may be due to EMA-1 gene sequence variables, the presence of PCR inhibitors, or parasitemia below the detection limit of the assays [1]. Theileria equi EMA-2 has been expressed in different expression systems: Baculovirus [54], Escherichia coli [52] and Pichia pastoris [53] The protein expressed in baculovirus has presented contamination with proteins as secreted by Sf9 cells [54], and by proteins produced by baculovirus itself which hinder its use in immunodiagnostic assays [52]. When expressed in E. coli, the EMA-2 protein was expressed in truncated form [44] and as a prokaryote system, the protein showed no posttranslational modifications. Flaws in protein folding can hide important epitopes this may interfere with the functioning of these proteins in immunodiagnostic tests or as antigens in recombinant vaccines $[55,56]$. In studies performed by our group [53], EMA-2 was expressed in the yeast P. pastoris and presented epitopes which were recognized by antibodies present in horse sera naturally infected with T. equi. From these results, an indirect ELISA was developed using the rEMA-2 protein as an antigen. The results obtained in these experiments were promising because the test showed a sensitivity of $\sim 91 \%$, and specificity of $\sim 83 \%$ [53].

\section{Treatment, Control and Prevention}

In endemic areas, treatments for theileriosis are used only as a means to reduce deaths and clinical signs of the disease. In nonendemic areas, trying to stay free of the disease, we find treatment of infected animals with the intention of clearing (chemical sterilization) [45]. Several studies have evaluated the potential use of vaccinations to induce immunity to $T$. equi infection, yet no vaccine is commercially available. There are also no specific drugs able to eliminate chronic $T$. equi infections or completely prevent infection in animals $[15,45,57,58]$. The existing medicines may however, control symptoms in acute infections and improve clinical signs though without completely eliminating the parasite $[15,58]$. However, data collected during an outbreak of equine theileriosis in Texas indicates that $T$. equi can be eliminated in infected horses with an appropriate dosage of imidocarb dipropionate [45]. There are a variety of non-specific drugs (imidocarb, tetracycline, diminazene, and buparvaquone) being used to control equine theileriosis, yet this makes it difficult to establish a treatment protocol [48]. Imidocarb in its dipropionate salt (ID) is considered to be the most effective non-specific drug. An alternative form of this drug, (dihydrochloride salt) causes more severe muscle damage at the injection site [45]. Measures such as euthanasia or quarantine of theileriosis positive animals can be used for those animals that have survived the acute phase of infection. To eliminate contact with the tick vector; avoiding transfer from one equine to another is also important to control the disease [58].

In non-endemic countries, prevention is done by regulating the movement of horses from endemic nations. Depending on the country, animals must test negative for T. equi in serological tests, usually cELISA or IFAT, as required by the importing country. If positive, entry of these animals is usually denied except for wellregulated sports events [45]. Application of acaricides before transport is also used to ensure that there is no introduction of ticks to clean animals [45].

\section{Conclusion}

Given the high prevalence and importance of equine theileriosis in endemic countries, studies to develop more 
sensitive and specific immunodiagnostic tests, specific drug and vaccines as well, becomes increasingly important. Thus, economic losses due to international blocking of horse transport from endemic countries to those considered free of the disease, can be minimized [59].

\section{References}

1. Alanazi AD, Said AE, Morin-Adeline V, Alyousif MS, Slapeta J (2014) Quantitative PCR detection of Theileria equi using laboratory workflows to detect asymptomatic persistently infected horses. Vet Parasitol 206(3-4): 138-145.

2. Mehlhorn H, Schein E (1998) Redescription of Babesia equi Laveran, 1901 as Theileria equi Mehlhorn, Schein 1998. Parasitol Res 84(6): 467- 475 .

3. Santos TM, Roier ECR, Santos HA, Pires MS, Vilela JAR, et al. (2011) Factors associated to Theileria equi in equids of two microregions from Rio de Janeiro, Brazil. Rev Bras Parasitol Vet 20(3).

4. Ramsay JD, Ueti MW, Johnson WC, Scoles GA, Knowles DP, et al. (2013) Lymphocytes and Macrophages are infected by Theileria equi, but T cells and B cells are not required to establish infection in vivo. PLoS One 8(10): e76996.

5. Mans BJ, Pienaar R, Latif AA (2015) A review of Theileria diagnostics and epidemiology. Int J Parasitol Parasites Wildl 4(1): 104-118.

6. Guimarães AM, Fábio RPB, Manoel JMR, Marina HFR, Adrianade MG, et al. (2016) Prevalence and risk factors of Theileria equi infection in horses in Minas Gerais, Brazil. Vet Parasito: Regional Stud Repo 3-4: 18-22.

7. Baldani CD, Hilario E, Nakaghi AC, Bertolini MC, Machado RZ (2011) Production of recombinant EMA-1 protein and its application for the diagnosis of Theileria equi using an enzyme immunoassay in horses from São Paulo State, Brazil. Rev Bras parasitol vet 20(1): 54-60.

8. Malekifard F, Tavassoli M, Yakhchali M, Darvishzadeh R (2014) Detection of Theileria equi and Babesia caballi using microscopic and molecular methods in horses in suburb of Urmia, Iran. Vet Res Forum 5(2): 129-133.

9. Levine ND (1985) Veterinary protozoology. Iowa State University Press, Iowa, USA, pp. 414.

10. Ikadai H, Sasaki M, Ishida H, Matsuu A, Igarashi I, et al. (2007) Molecular evidence of Babesia equi transmission in Haemaphysalis longicornis. Am J Trop Med Hyg 76(4): 694-697.

11. Labruna MB, Kerber CE, Ferreira F, Faccini JL, De Waal DT, et al. (2001) Risk factors to tick infestations and their ocurrence on horses in the state of São Paulo, Brazil. Vet Parasitol 97(1): 1-14.

12. Volpato A, Agostini M, Tonin AA, da Silva AS (2013) High infestation by Rhipicephalus (Boophilus) microplus in a mare: a rare case report. Comparative Clinical Pathology 22(6): 1263-1265.

13. Uilenberg G (2006) Babesia-A historical overview. Vet Parasitol 138(12): 3-10.

14. Allsopp MT, Cavalier-Smith T, De Waal DT, Allsopp BA (1994) Phylogeny and evolution of the piroplasm. Parasitology 108(Pt 2): 147-152.

15. Kerber CE, Labruna MB, Ferreira F, De Waal DT, Knowles DP, et al. (2009) Relevance of equine Piroplasmosis and its association with tick infestation in the State of São Paulo, Brazil. Rev Bras Parasitol Vet 18(4): 1-8.

16. Urquhart GM, et al. (1996) Veterinary Parasitology. (2 $\left.2^{\text {nd }} e d n\right)$, Blackwell Science Ltd, Oxford, UK.

17. Ueti MW, Palmer GH, Scoles GA, Kappmeyer LS, Knowles DP (2008) Persistently infected horses are reservois for intrastadial tick-borne transmission of the Apicomplexan Parasite Babesia equi. Infect Immun 76(8): 3525-3529.
18. Phipps LP, Otter A (2004) Transplacental transmission of Theileria equi in two foals born and reared in the United Kingdom. Vet Rec 154(13): 406-408.

19. Georges KC, Ezeokoli CD, Sparagano O, Pargass I, Campbell M, et al. (2011) A case of transplacental transmission of Theileria equi in a foal in Trinidad. Vet Parasitol 175(3-4): 363-366.

20. Chhabra S, Ranjan R, Uppal SK, Singla LD (2012) Transplacental transmission of Babesia equi (Theileria equi) from carrier mares to foals. J Parasit Dis 36(1): 31-33.

21. Sant C, d'Abadie R, Pargass I, Basu AK, Asgarali Z, et al. (2016) Prospective study investigating transplacental transmission of equine piroplasmosis in thoroughbred foals in Trinidad. Vet Parasitol 226: 132-137.

22. Heim A, Passos LM, Ribeiro MF, Costa-Júnior LM, Bastos CV, et al. (2007) Detection and molecular characterization of Babesia caballi and Theileri equi isolates from endemic areas of Brazil. Parasitol Res 102(1): 63-68.

23. Verwoerd DW, Penzhorn BL (2005) J Equine piroplasmosis. In: Coetzer JAW, Tustin RC (Eds.). Infectious Diseases of Livestock ( $2^{\text {nd }}$ ed.), Oxford University Press, New York, USA, pp. 425-434.

24. Schein E (1988) Equine babesioses. In: Ristic M. (Ed.) Babesiosis of domestic animals and man. CRS Press, Florida, USA, pp. 197-208.

25. Roncati NV et al. (2011) Occurrence of congenital in Theileria equi Lusitano pure blood foals, diagnosed by RT-PCR. Education Journal in Veterinary Medicine and Zootechny of CRMV-SP. São Paulo 9(1): 46-52.

26. Oie (Officer Internacional dês Epizooties) (2012) Manual of Diagnostic Tests and Vaccines for Terrestrial Animals.

27. Rothschild C, Knowles D (2007) Equine Piroplasmosis. In: Sellon DC, Long MT (Eds.), Equine Infections Diseases. Saunders, Elsevier, St Louis, USA, pp. 465-473.

28. Mealey RH, Kappmeyer LS, Ueti MW, Wagner B, Knowles DP (2012) Protective Effects of Passively Transferred Merozoite-Specific Antibodies against Theileria equi in Horses with Severe Combined Immunodeficiency. Clin Vaccine Immunol 19(1): 100-104.

29. Knowles DP, Kappmeyer LS, Perryman LE (1994) Specific immune responses are required to control parasitemia in Babesia equi infection. Infect Immun 62(5): 1909-1913.

30. Kumar S, Yokoyama N, Kim JY, Huang X, Inoue N, et al. (2004) Expression of Babesia equi EMA-1 and EMA-2 during merozoite developmental stages in erythrocyte and their interaction with erythrocytic membrane skeleton. Molecular and Biochemical Parasitology 133(2): 221-227.

31. Nizoli LQ Conceição FR, Silva SS, Dummer LA, Santos AG, et al. (2009) Immunogenicity and antigenicity of the recombinant EMA-1 protein of Theileria equi expressed in the yeast Pichia pastoris. Rev Bras Parasitol Vet 18(2): 1-4.

32. Knowles DP, Perryman LE, Goff WL, Miller CD, Harrington RD, et al. (1991) A monoclonal antibody defines a geographically conserved surface protein of Babesia equi merozoítos. Infect Immun 59(7): 23142417.

33. Kappmeyer LS, Perryman LE, Knowles DP (1993) A Babesia equi gene encodes a surface protein with homology to Theileria species. Mol Biochem Parasitol 62(1): 121-124.

34. Kappmeyer LS, Thiagarajan M, Herndon DR, Ramsay JD, Caler E, et al. (2012) Comparative genomic analysis and phylogenetic position of Theileria equi. BMC Genomics 13: 603.

35. Silva MG, Graça T, Suarez CE, Knowles DP (2013) Repertoire of Theileria equi immunodominant antigens bound by equine antibody. Mol Biochem Parasitol 188(2): 109-115.

36. Ikadai H, Ishida H, Sasaki M, Taniguchi K, Miyata N, et al. (2006) Molecular cloning and partial characterization of Babesia equi EMA-3. Mol Biochem Parasitol 150(2): 371-373. 
37. Knowles DP, Kappmeyer LS, Perryman LE (1997) Genetic and biochemical analysis of erythrocyte-stage surface antigens belonging to a family of highly conserved proteins of Babesia equi and Theileria species. Mol Biochem Parasitol 90(1): 69-79.

38. Kim JY, Yokoyama N, Kumar S, Inoue N, Yamaguchi T, et al. (2004) Molecular epidemiological survey of benign Theileria parasites of cattle in Japan: detection of a new type of major piroplasm surface protein gene. J Vet Med Sci 66(3): 251-256.

39. Aparna M, Vimalkumar MB, Varghese S, Senthilvel K, Ajithkumar KG (2013) Phylogenetic analysis of bovine Theileria spp. isolated in south India. Tropical Biomedicine 30(2): 281-290.

40. Kumar S, Yokoyama N, Kim JY, Bork-Mimm S, Inoue N, et al. (2012) Theileria equi merozoite antigen-2 interacts with actin molecule of equine erythrocyte during their asexual development. Exp Parasitol 132(4): 508-512.

41. Bargieri DY, Andenmatten N, Lagal V, Thiberge S, Whitelaw JA, et al (2013) Apical membrane antigen 1 mediates apicomplexan parasite attachment but is dispensable for host cell invasion. Nat Commun 4 2552.

42. Preiser P, Kaviratne M, Khan S, Bannister L, Jarra W (2000) The apical organelles of malaria merozoites: host cell selection, invasion, host immunity and immune evasion. Microbes Infect 2(12): 1461-1477.

43. Knowles DP, Kappmeyer LS, Stiller D, Hennager SG, Perryman LE (1992) Antibody to a recombinant merozoite protein epitope identified horses infected with Babesia equi. J Clin Microbiol 30(12): 3122-3126.

44. Kumar S, Kumar R, Gupta AK, Yadav SC, Goyal SK, et al. (2013) Development of EMA-2 recombinant antigen-based enzyme-linked immunosorbent assay for seroprevalence studies of Theileria equi in Indian equine population. Vet Parasitol 198(1-2): 10-17.

45. Wise LN, Kappmeyer LS, Mealey RH, Knowles DP (2013) Review of Equine Piroplasmosis. J Vet Intern Med 27(6): 1334-1346.

46. Kumar S, Malhotra DV, Dhar S, Nichani AK (2002) Vaccination of donkeys against Babesia equi using killed merozoite immunogen. Vet Parasitol 106(1): 19-33.

47. Cunha CW, Mc Guire TC, Kappmeyer LS, Hines SA, Lopez AM (2006) Development of Specific Immunoglobulin Ga (IgGa) and IgGb Antibodies Correlates with Control of Parasitemia in Babesia equi Infection. Clin Vaccine Immunol 13 (2): 297-300.

48. Radostits OM, Gay C, Hinchcliff K, Constable P (2007) Medicine Veterinary - A Textbook of the Diseases of Cattle, Horses, Sheep, Pigs, and Goats. (10 edn), Saunders, Philadelphia, USA, pp. 673-762.
49. Farnaz M, Tavassoli M, Yakhchali M, Darvishzadeh R (2014) Detection of Theileria equi and Babesia caballi using microscopic and molecular methods in horses in suburb of Urmia, Iran. Vet Res Forum 5(2): 129133.

50. Abutarbush SM, Alqawasmeh DM, Mukbel RM, Al-Majali AM (2011) Equine Babesiosis: Seroprevalence, Risk Factors and Comparison of Different Diagnostic Methods in Jordan. Transbound Emerg Dis 59(1): 72-78.

51. Farkas R, Tánczos B, Gyurkovszky M, Földvári G, Solymosi N, et al. (2013) Serological and molecular detection of Theileria equi infection in horses in Hungary. Vet Parasitol 192(1-3): 143-148.

52. Huang X, Xuan X, Yokoyama N, Xu L, Suzuki H, et al. (2003) High-Level Expression and Purification of a Truncated Merozoite Antigen-2 of Babesia equi In Escherichia coli and its Potential for Immunodiagnosis. J Clin Microbiol 41(3): 1147-1151.

53. Vianna AM, Gonçales RA, Lara APSS, Pinto LS, Nizoli QL, et al. (2014) Heterologous expression of EMA-2 (equi merozoite antigen) of Theileria equi in Pichia pastoris with potential use in immunobiologics. Ciencia Rural 44(10): 1830-1836.

54. Tanaka T, Xuan X, Ikadai H, Igarashi I, Nagasawa H, et al. (1999) Expression of Babesia equi merozoite antigen-2 by recombinant baculovirus and its use in the ELISA. Int J Parasitol 29(11): 1803-1808.

55. Faisal SM, Yan W, Chen CS, Palaniappan RU, McDonough SP, et al (2008) Evaluation of protective immunity of Leptospira immunoglobulin like protein A (LigA) DNA vaccine against challenge in hamsters. Vaccine 26(2): 277-287.

56. Pinheiro AF, Borsuk S, Berne ME, Pinto Lda S, Andreotti R, et al. (2013) Expression of Neospora caninum NcSRS2 surface protein in Pichia pastoris and its application for serodiagnosis of Neospora infection. Pathog Glob Health 103(3): 116-121.

57. Kerber CE, Ferreira F, Pereira MC (1999) Control of equine piroplasmosis in Brazil. Onderstepoort J Vet Re 66(2): 123-127.

58. Bahrami S, Ghadrdan AR, Mirabdollahi SM, Fayed MR (2014) Diagnosis of subclinical equine theileriosis in center of Iran using parasitological and molecular methods. Trop Biomed 31(1): 110-117.

59. Knowles DP (1995) Equine piroplasmosis: a review. Br Vet J 148(1): 6-14.

\section{Your next submission with Juniper Publishers} will reach you the below assets

- Quality Editorial service

- Swift Peer Review

- Reprints availability

- E-prints Service

- Manuscript Podcast for convenient understanding

- Global attainment for your research

- Manuscript accessibility in different formats

( Pdf, E-pub, Full Text, Audio)

- Unceasing customer service

Track the below URL for one-step submission https://juniperpublishers.com/online-submission.php 